\title{
Online Learning with Project Based Learning Approach in the Human Performance Technology Course
}

\author{
Beatriks Lasamahu1*, Eveline Siregar ${ }^{2}$, Moch Sukardjo ${ }^{3}$ \\ 1,2,3 Department of Educational Technology, Postgraduate Program, State University of Jakarta, Jakarta, Indonesia
}

\section{A R T I CLE I N F O}

Article history:

Received February 18, 2021

Revised February 20, 2021

Accepted April 19, 2021

Available online May 25, 2021

Kata Kunci :

Pembelajaran Online, Desain,

Pembelajaran Berbasis Proyek

\section{Keywords:}

Online Learning, Design, Project Based Learning

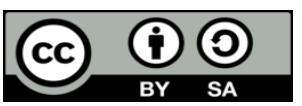

This is an open access article under the CC BY-SA license.

Copyright $($ C) 2021 by Author. Published by Universitas Pendidikan Ganesha.

\begin{abstract}
A B S T R A K
Perkembangan era dan revolusi 4.0 menuntut perguruan tinggi untuk mampu menjawab tantangan menghadapi kemajuan teknologi dan persaingan dunia kerja di era globalisasi. Pembelajaran online merupakan salah satu bentuk pembelajaran yang dapat menjawab perkembangan zaman, kemajuan teknologi dan perkembangan ilmu pengetahuan di perguruan tinggi. Penelitian ini bertujuan untuk merancang pembelajaran online dengan pendekatan Project Based Learning pada mata kuliah Human Performance Technology. Penelitian ini menggunakan metode $R \& D$ dalam merancang pembelajaran online. Desain pembelajaran online dilakukan dengan menggunakan model PEDATI. Model PEDATI sendiri memiliki beberapa langkah desain mulai dari merumuskan pembelajaran online, memetakan materi, menentukan asinkron atau sinkron dan merancang jalur pembelajaran yang dipilih. Pembelajaran asinkron di PEDATI yang terdiri dari, pendalaman, penerapan dan evaluasi dengan pendekatan pembelajaran berbasis proyek yang memiliki enam langkah. Hasil penelitian menghasilkan desain pembelajaran online yang terdiri dari merumuskan hasil belajar, memetakan materi, membuat alur pembelajaran asinkron yang dipadukan dengan sintaks pembelajaran berbasis proyek. Pemilihan materi, bentuk diskusi, tugas hingga formulir evaluasi dapat diatur sedemikian rupa dan dipadukan dengan LMS yang digunakan. Desain pembelajaran online yang didesain dengan aktivitas pembelajaran yang tepat dapat menjadikan pembelajaran lebih bermakna bagi siswa. Dengan pembelajaran online, pembelajaran tatap muka dapat menjadi sarana diskusi bukan hanya sekedar penyampaian materi.
\end{abstract}

\section{A B S T R A C T}

The development of the era and the 4.0 revolution requires universities to be able to answer challenges to face technological advances and competition in the world of work in the era of globalization. Online learning is a form of learning that can answer the times, technological advances and knowledge of learning development in universities. This study aims to design the online learning with Project Based Learning approach in the Human Performance Technology course. This study uses the R\&D method in designing online learning. The online learning design is carried out using the PEDATI model. The PEDATI model itself has several design steps starting from formulating online learning, mapping material, determining asynchronous or synchronous and designing the selected learning path. Asynchronous learning at PEDATI which consists of, deepening, applying and evaluating with a project-based learning approach that has six steps. The results of the research resulted in an online learning design which consisted of formulating learning outcomes, mapping materials, making asynchronous learning flows combined with project-based learning syntax. Selection of materials, forms of discussion, assignments to evaluation forms can be arranged in such a way and combined with the LMS used. Online learning designs that are designed with the right learning activities can make learning more meaningful for students. With online learning, face-to-face learning can be a means of discussion rather than just delivering material.

\section{INTRODUCTION}

The development of the era and the 4.0 revolution requires universities to be able to answer challenges to face technological advances and competition in the world of work in the era of globalization (Fitriyani et al., 2020; Mustofa et al., 2019; Nash \& Churchill, 2020). Every higher education plan to face the era of the industrial revolution 4.0 must be built with hybrid online and in-person instructions, seamless use of video conferences, and more asynchronous learning resources. Blended Instruction and optimization of flipped and online courses will create an efficient learning environment that can adapt to differences in student learning preparation (Iswatiningsih et al., 2020; Siripongdee et al., 2020). Adjustment of learning facilities and infrastructure and the availability of learning resources in terms of information technology, internet, big data analysis and computerization are needed so that students can 
optimize the learning process better, with the hope that college graduates have soft skills, ethics, critical thinking, cultured and innovative (Budiyono, 2020).

The use and utilization of digital technology and the development of flexible learning spaces can be done through online learning (Eliyana, 2020; Satrianingrum \& Prasetyo, 2020; Yuzulia, 2021). Online learning can support learning activities that can occur anytime, anywhere and with anyone. Online learning is open learning using pedagogical tools that make it possible for the internet and web-based to facilitate learning and knowledge building through meaningful interactions (Dabbagh \& Bannan-Ritland, 2005). The three components contained in online learning are Pedagogical models or constructs, Strategic Instructional, and Learning technologies. Application of certain learning strategies such as collaborative learning, presentations, simulations. Learning technology is defined as a pattern of presenting material such as synchronus or asynchronous, application of the concept of hypermedia, multimedia, use of LMS / LCMS. Besides that, the pedagogical model is related to the form of online learning itself, namely flexible learning, distributed learning, and so on. These three components, working as a system, support each other in creating a learning model through cyberspace. (Prawiradilaga \& Chaeruman, 2018).

Online learning that is designed must be supported by the selection of pedagogical models (Logan et al., 2021; Majid \& Stapa, 2017), the pedagogical model used is project based learning, the selection of this model is based on the characteristics and needs of the course being designed. Project based learning is a learning method that uses projects / activities as a medium (Abdel Halim, 2011; Izati et al., 2018; Marzuki \& Basariah, 2017). Project based learning consists of 6 steps. The steps in the project based learning method can be seen in Figure 1.

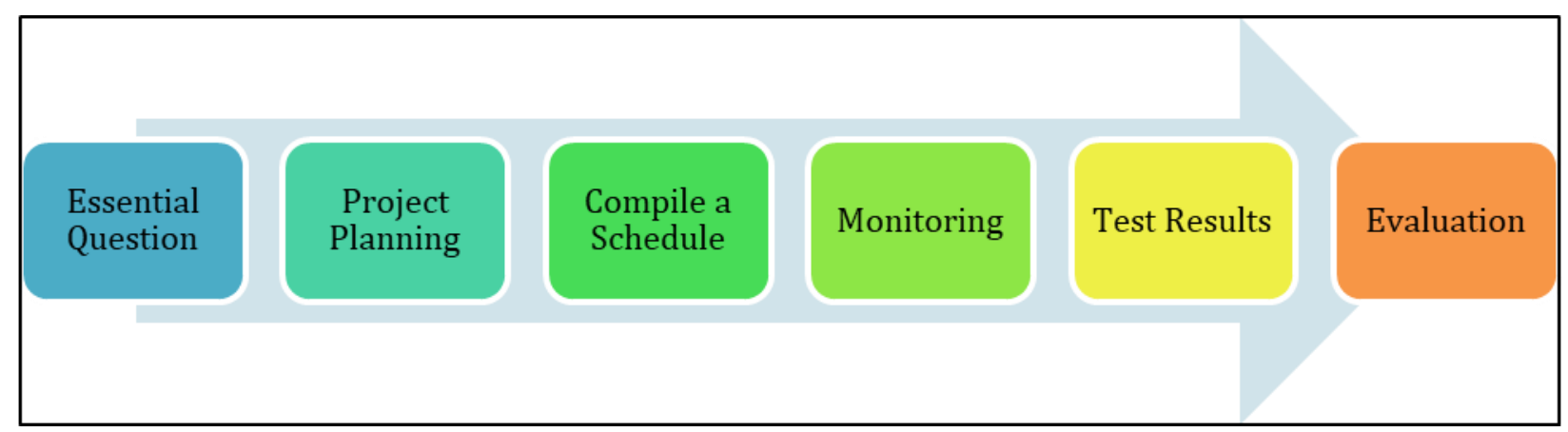

Figure 1. Project Based Learning Steps

This study aims to design the online learning with Project Based Learning approach in the Human Performance Technology course. The design starts from the formulation of learning achievement, mapping the material, designing the asynchronous learning flow and selecting media and activities which are steps of the PEDATI model. The project based learning method is used to highlight the characteristics of the human performance technology course, which not only discusses theory but also the skills students must possess.

\section{METHODS}

In this study using the Research and Development (R \& D) method. Research and development (R\&D) is a type of research used by researchers in research to produce new product designs, test the effectiveness of existing products, and develop and create new products (Sugiyono, 2015; Tegeh et al., 2015). This research is a series of online learning development research. In this study, after conducting a literature review on online learning design and human performance technology courses, the researcher will try to map the competency standards of subjects packaged in the PEDATI model with a project-based learning approach to analyze whether or not they are appropriate. Due to the scope of the study, this study was limited to design only. Online learning can be designed using the PEDATI model (Febriantoro, 2018; Lasamahu et al., 2021). PEDATI stands for learn, explore, apply and evaluate, which is a cycle in learning. The PEDATI model has a sequence of 1) formulating learning outcomes, 2) mapping and organizing the material, 3) selecting and determining synchronous or asynchronous, 4) designing synchronous or asynchronous learning activities. After determining the learning activities to be used, the next step is to create a synchronous or asynchronous learning flow. The Learning Flow of the PEDATI Model is presented in Figure 2. 


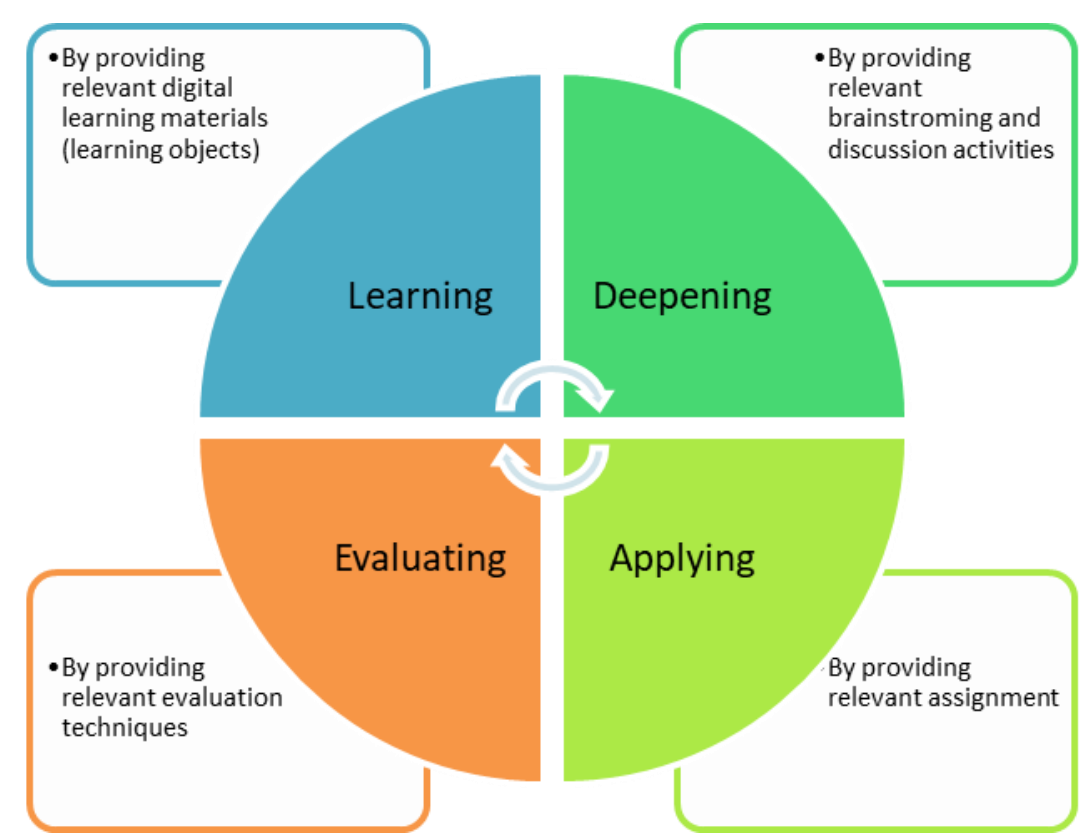

Figure 2. The Learning Flow of the PEDATI Model (Chaeruman et al., 2020)

\section{RESULT AND DISCUSSION}

\section{Results}

Online learning design uses the PEDATI model combined with project based learning methods. Each stage of the process in the model is synchronized and ends in the same process. The following is an online learning design using the PEDATI Model. The first step in planning is to formulate the learning outcomes of the course. The formulation of learning outcomes must contain four elements A (Audiace), B (behavior) C (condition) and D (degree). The formulation of learning outcomes in the Human performance technology course consists of seven learning outcomes which are then divided into several sub learning outcomes. The examples of learning outcomes and human performance technology sub-courses presented in Table 1.

Table 1. Examples of Learning Outcomes and Sub-achievements

\begin{tabular}{|c|c|}
\hline $\begin{array}{l}\text { Learning Outcomes } \\
\text { Courses }\end{array}$ & Sub Learning Outcomes \\
\hline $\begin{array}{l}\text { Students can conceptually analyze } \\
\text { the context of the position and limits } \\
\text { of performance technology within }\end{array}$ & $\begin{array}{l}\text { a. Students can state the meaning of Performance } \\
\text { Technology in the Educational Technology section } \\
\text { appropriately. }\end{array}$ \\
\hline $\begin{array}{l}\text { the TP } 2004 \text { Definition framework } \\
\text { properly and correctly through } \\
\text { project assignments. }\end{array}$ & $\begin{array}{l}\text { b. Students can define the boundaries of the Area as } \\
\text { "improving performance" well. }\end{array}$ \\
\hline $\begin{array}{l}\text { Students can identify the } \\
\text { characteristics of performance }\end{array}$ & $\begin{array}{l}\text { a. Students can explain the definition and model form of } \\
\text { Human performance technology well }\end{array}$ \\
\hline technology properly and correctly & $\begin{array}{l}\text { b. Students can relate the role of the system to the } \\
\text { performance of an organization well }\end{array}$ \\
\hline $\begin{array}{l}\text { Students can describe the meaning } \\
\text { and categories of intervention in the }\end{array}$ & $\begin{array}{l}\text { a. Students can explain the meaning of the intervention } \\
\text { well }\end{array}$ \\
\hline $\begin{array}{l}\text { context of performance technology } \\
\text { properly }\end{array}$ & $\begin{array}{l}\text { b. Students can put forward the category of intervention } \\
\text { according to the opinion of the experts appropriately. }\end{array}$ \\
\hline $\begin{array}{l}\text { Students can apply the concept of } \\
\text { performance analysis and training }\end{array}$ & $\begin{array}{l}\text { a. Students can compile a form of performance analysis } \\
\text { well. }\end{array}$ \\
\hline $\begin{array}{l}\text { overview as part of the learning } \\
\text { intervention properly and correctly } \\
\text { through project assignments. }\end{array}$ & $\begin{array}{l}\text { b. Students can explain training as an intervention and its } \\
\text { position in an organization well. }\end{array}$ \\
\hline $\begin{array}{l}\text { Students can analyze the systems } \\
\text { approach in training development }\end{array}$ & $\begin{array}{l}\text { a. Students can determine the system concept in training } \\
\text { development well. }\end{array}$ \\
\hline
\end{tabular}




\begin{tabular}{lll}
\hline \multicolumn{1}{c}{$\begin{array}{c}\text { Learning Outcomes } \\
\text { Courses }\end{array}$} & \multicolumn{1}{c}{ Sub Learning Outcomes } \\
\hline properly. & b. & $\begin{array}{l}\text { Students can describe the steps to develop the training } \\
\text { appropriately. }\end{array}$ \\
$\begin{array}{l}\text { Students can analyze the roles and } \\
\text { functions of current organizational } \\
\text { interventions as well. }\end{array}$ & a. & $\begin{array}{l}\text { Students can describe the Performance Management } \\
\text { System and its application in organizations as part of } \\
\text { contemporary interventions properly. }\end{array}$ \\
$\begin{array}{l}\text { Students can design a performance } \\
\text { improvement program well through } \\
\text { project assignments }\end{array}$ & b. $\begin{array}{l}\text { Students can describe appropriate approaches that can } \\
\text { be used to improve the quality of performance. }\end{array}$ \\
& a. $\begin{array}{l}\text { Students in groups can choose performance } \\
\text { improvement development activities with a certain } \\
\text { model well based on the objectives and characteristics } \\
\text { of the training well. } \\
\text { Students can provide an example of a development } \\
\text { model that can be used to properly design } \\
\text { performance improvement programs. }\end{array}$ \\
\hline
\end{tabular}

After determining learning outcomes The next step is to map and organize the learning material. Based on learning outcomes, it is necessary to map and organize the materials that will be developed into online learning. Mapping and organizing learning material for human performance technology courses begins with learning outcomes which are the subject and sub-learning outcomes become sub-subjects. Each subject is mapped into several main subjects. Examples of Mapping and Organizing Learning Materials is presented in Table 2.

Table 2. Examples of Mapping and Organizing Learning Materials

\begin{tabular}{|c|c|c|}
\hline Subject & Sub Topics & subject matter \\
\hline \multirow{8}{*}{$\begin{array}{l}\text { Technology } \\
\text { performance } \\
\text { characteristics }\end{array}$} & $\begin{array}{l}\text { The Meaning of Performance } \\
\text { Technology in TP }\end{array}$ & $\begin{array}{l}\text { Definition of performance technology in the essence } \\
\text { of TP definition (AECT 2004) } \\
\text { Existence of Performance Technology }\end{array}$ \\
\hline & \multirow{2}{*}{$\begin{array}{l}\text { Area Boundary "Improving } \\
\text { Performance" }\end{array}$} & Improve student performance individually \\
\hline & & Improve the performance of Teachers and Designers \\
\hline & \multirow{2}{*}{$\begin{array}{l}\text { Human Performance } \\
\text { Technology }\end{array}$} & $\begin{array}{l}\text { Improve organizational performance } \\
\text { Definition of Human Performance Technology. }\end{array}$ \\
\hline & & $\begin{array}{l}\text { Engineering human performance (Model HPT } \\
\text { Strategic Impact) }\end{array}$ \\
\hline & \multirow[t]{3}{*}{ Learning Organization } & Learning in organizations (organizational learning) \\
\hline & & $\begin{array}{l}\text { A systems perspective on organizational } \\
\text { performance }\end{array}$ \\
\hline & & $\begin{array}{l}\text { The important role of the thinking system as the } \\
\text { foundation for } \mathrm{OB}\end{array}$ \\
\hline \multirow{5}{*}{$\begin{array}{l}\text { Interventions } \\
\text { in the context } \\
\text { of } \\
\text { performance } \\
\text { technology }\end{array}$} & \multirow[t]{2}{*}{ Meaning of Intervention } & Definition of Intervention \\
\hline & & Impact of Intervention \\
\hline & \multirow[t]{3}{*}{ Intervention Category } & Opinions of Van Tiem, et al., And Silber \\
\hline & & Opinions of Van Tiem, Moseley and Dessinger \\
\hline & & Opinions of Stolovich \& Keeps, et al \\
\hline \multirow{6}{*}{$\begin{array}{l}\text { Learning } \\
\text { Interventions }\end{array}$} & \multirow[t]{3}{*}{ Performance Analysis } & Performance, Knowledge \& Job review \\
\hline & & Performance analysis model \\
\hline & & $\begin{array}{l}\text { Information / data collection methods and } \\
\text { techniques for performance analysis } \\
\text { Training need analysis }\end{array}$ \\
\hline & \multirow{3}{*}{$\begin{array}{l}\text { Training as a classic } \\
\text { intervention }\end{array}$} & Training as an intervention \\
\hline & & Position of Training in Organizations \\
\hline & & Impact of Training \\
\hline \multirow{4}{*}{$\begin{array}{l}\text { A systems } \\
\text { approach in } \\
\text { training } \\
\text { development. }\end{array}$} & \multirow[t]{2}{*}{ System in training } & Systems Concept in Training \\
\hline & & Training development with a systems approach \\
\hline & \multirow{2}{*}{$\begin{array}{l}\text { Training development with a } \\
\text { systems approach }\end{array}$} & Analysis \\
\hline & & Design \\
\hline
\end{tabular}




\begin{tabular}{lll}
\hline Subject & Sub Topics & subject matter \\
\hline & & development \\
& & Implementation \\
& & Evaluation \\
Current & Performance Management & Definition of Performance Management System \\
intervention & System and its application in & Implementation of Performance Management \\
Performance & organizations & System in organizations \\
technology & Approach in improving the & Various approaches in improving the quality of \\
& quality of performance & performance (ARCS, Corporate University etc.) \\
& & Current performance issues and solutions \\
Students can & Performance improvement & Needs analysis activities \\
design a & development activities & Design activities \\
performance & & Development activities \\
improvement & & Implementation Activities \\
program well & & Evaluation Activities \\
through & Performance improvement & Requirement's analysis design \\
project & program design & Design \\
assignments & & Design development \\
& & Implementation Design \\
& & Evaluation Design \\
\hline
\end{tabular}

Choosing asynchronous and synchronous learning. Based on mapping and organizing the materials to be developed in online learning, materials that are asynchronous and synchronous will be selected. In research, the focus of research is more on the design of making online learning, for that all material in performance technology courses is made in the form of online learning as a whole. Designing asynchronous learning activities At this stage the asynchronous learning activities, namely Learn, Deep, Apply and Evaluate combined with the Project based learning syntax. The syntax for project based learning has six steps starting from making basic questions in the learning section to the last part in the evaluation section. The complete design of the PEDATI model with a combination of project based learning methods can be seen in Figure 3.
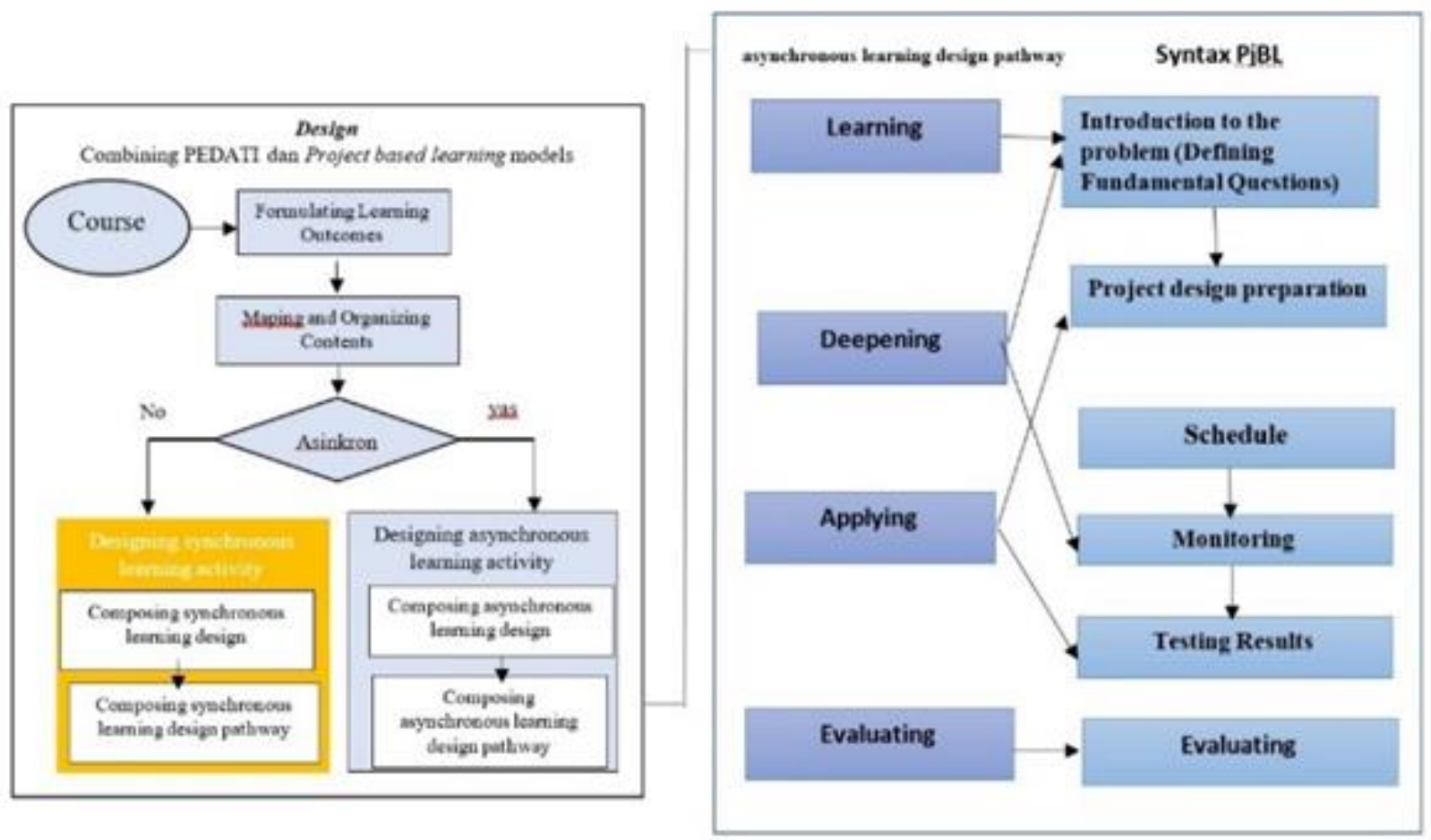

Outside the research focus

Figure 3. Combination of PEDATI model with Project Based Learning 
Asynchronous learning activities can be divided into independent asynchronous and collaborative asynchronous, in which there are media, evaluation tests, discussions and online assignments. The selection of each component is adjusted to the sub-topic and characteristics of the selected media or activity. The division of asynchronous activities can be seen in Table 3 .

Table 3. Examples of designing asynchronous activities

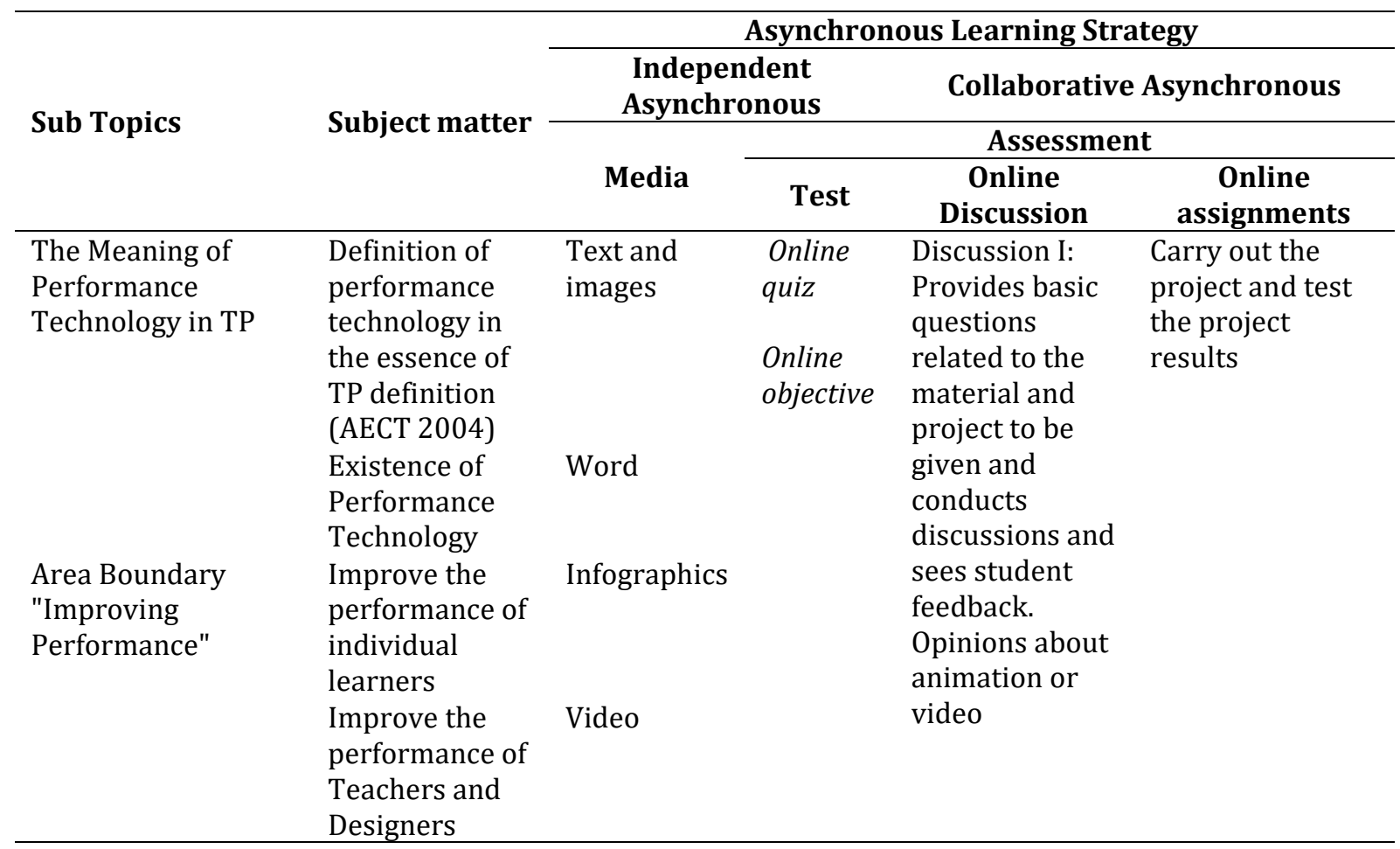

\section{Discussion}

The development of the era and the 4.0 revolution requires universities to be able to answer challenges to face technological advances and competition in the world of work in the era of globalization (Fitriyani et al., 2020; Mustofa et al., 2019; Nash \& Churchill, 2020). Every higher education plan to face the era of the industrial revolution 4.0 must be built with hybrid online and in-person instructions, seamless use of video conferences, and more asynchronous learning resources. Blended Instruction and optimization of flipped and online courses will create an efficient learning environment that can adapt to differences in student learning preparation (Iswatiningsih et al., 2020; Siripongdee et al., 2020). Adjustment of learning facilities and infrastructure and the availability of learning resources in terms of information technology, internet, big data analysis and computerization are needed so that students can optimize the learning process better, with the hope that college graduates have soft skills, ethics, critical thinking, cultured and innovative (Budiyono, 2020).

The use and utilization of digital technology and the development of flexible learning spaces can be done through online learning (Eliyana, 2020; Satrianingrum \& Prasetyo, 2020; Yuzulia, 2021). Online learning can support learning activities that can occur anytime, anywhere and with anyone. Online learning is open learning using pedagogical tools that make it possible for the internet and web-based to facilitate learning and knowledge building through meaningful interactions (Dabbagh \& Bannan-Ritland, 2005). The three components contained in online learning are Pedagogical models or constructs, Strategic Instructional, and Learning technologies. Application of certain learning strategies such as collaborative learning, presentations, simulations. Learning technology is defined as a pattern of presenting material such as synchronus or asynchronous, application of the concept of hypermedia, multimedia, use of LMS / LCMS. Besides that, the pedagogical model is related to the form of online learning itself, namely flexible learning, distributed learning, and so on. These three components, working as a system, support each other in creating a learning model through cyberspace. (Prawiradilaga \& Chaeruman, 2018).

Online learning that is designed must be supported by the selection of pedagogical models (Logan et al., 2021; Majid \& Stapa, 2017), the pedagogical model used is project-based learning, the selection of this model is based on the characteristics and needs of the course being designed. Project based learning is a learning method that uses projects / activities as a medium (Abdel Halim, 2011; Izati et al., 2018; 
Marzuki \& Basariah, 2017). Project based learning consists of 6 steps. An asynchronous learning flow that includes instructions, descriptions, a series of independent asynchronous activities (digital media and quizzes / tests) and a series of asynchronous collaborative activities (discussion forums and online assignments) arranged inductively or deductively into an interactive, interesting and able learning object. resulting in an optimal learning experience. The asynchronous learning flow combined with the Project based learning model approach produces a sequence of learning activities that unites the asynchronous flow with six steps of integrated project based learning. After completing all stages of the online learning design with a project-based learning approach, the next step can be continued by preparing online materials for study, and preparing projects that will be used with the appropriate project appraisal instrument. Online learning media can be included according to the flow of the learning technology used, LMS can also be designed in such a way as to attract learners in taking online learning.

\section{CONCLUSION}

Online learning in higher education helps students to have rich learning resources and learning opportunities anywhere. The design starts from the formulation of learning achievement, mapping the material, designing the asynchronous learning flow and selecting media and activities which are steps of the PEDATI model. The project based learning method is used to highlight the characteristics of the human performance technology course, which not only discusses theory but also the skills students must possess. Online learning is designed by combining the steps in the PEDATI model with project based learning syntax. Selection of materials, forms of discussion, assignments to evaluation forms can be arranged in such a way and combined with the LMS used. Online learning designs that are designed with the right learning activities can make learning more meaningful for students. With online learning, face-toface learning can be a means of discussion rather than just delivering material.

\section{REFERENCES}

Abdel Halim, S. M. (2011). Improving EFL majors' critical reading skills and political awareness: A proposed translation program. International Journal of Educational Research, 50(5-6), 336-348. https://doi.org/10.1016/j.ijer.2011.11.003.

Budiyono, B. (2020). Inovasi Pemanfaatan Teknologi Sebagai Media Pembelajaran di Era Revolusi 4.0. Jurnal Kependidikan: Jurnal Hasil Penelitian Dan Kajian Kepustakaan Di Bidang Pendidikan, Pengajaran Dan Pembelajaran, 6(2), 300. https://doi.org/10.33394/jk.v6i2.2475.

Dabbagh, N., \& Bannan-Ritland, B. (2005). Online learning: Concepts, strategies, and application. Pearson.

Eliyana, E. (2020). Analisis Keterampilan Proses Sains Siswa Belajar IPA Materi Tumbuhan Hijau Pada Siswa Kelas V SDN 3 Panjerejo di Masa Pandemi Covid-19. EDUPROXIMA: Jurnal Ilmiah Pendidikan IPA, 2(2), 87. https://doi.org/10.29100/eduproxima.v2i2.1628.

Febriantoro, W. (2018). Blended Learning Instructional Design Development On The Prepackaged Products Training Using Pedati Model. Science, Engineering, Education, and Development Studies (SEEDS): Conference Series. https://jurnal.uns.ac.id/seeds/article/view/24648.

Fitriyani, Y., Fauzi, I., \& Sari, M. Z. (2020). Motivasi Belajar Mahasiswa Pada Pembelajaran Daring Selama Pandemik Covid-19. Jurnal Kependidikan: Jurnal Hasil Penelitian Dan Kajian Kepustakaan Di Bidang Pendidikan, Pengajaran Dan Pembelajaran, 6(2), 165-175. https://doi.org/10.23917/ppd.v7i1.10973.

Iswatiningsih, D., Fauzan, Dluhayati, \& Lestari, Y. K. (2020). Efektivitas Pembelajaran Bahasa Indonesia Daring di Masa Pandemi COVID-19 Dalam Meningkatkan Kemampuan Berbahasa Siswa SMP. Jurnal Pendidikan, Kebahasaan Dan Kesustraan Indonesia, 5, 141-156.

Izati, S. N., Wahyudi, \& Sugiyarti, M. (2018). Project Based learning berbasis Literasi untuk Meningkatkan Hasil Belajar Tematik. Jurnal Pendidikan, 3(9), 1122-1127. https://doi.org/10.17977/jptpp.v3i9.11508.

Lasamahu, B., Siregar, E., \& Sukardjo, M. (2021). Using PEDATI Model to Design Online Learning with Project Based Learning Approach in the Human Performance Technology Course. Journal of Education Research and Evaluation, 5(2). https://doi.org/10.23887/jere.v5i2.32387.

Logan, R. M., Johnson, C. E., \& Worsham, J. W. (2021). Development of an E-learning Module to Facilitate Student Learning and Outcomes. Teaching and Learning in Nursing, 16(2), 139-142. https://doi.org/10.1016/j.teln.2020.10.007.

Majid, A. H. A., \& Stapa, S. H. (2017). The use of scaffolding technique via Facebook in improving descriptive writing among ESL Learners. 3L: Language, Linguistics, Literature, 23(4), 77-88. 
https://doi.org/10.17576/3L-2017-2304-07.

Marzuki, \& Basariah. (2017). The Influence Of Problem-Based Learning And Project Citizen Model In The Civic Education Learning On Student'scritical Thinking Ability And Self Discipline. Cakrawala Pendidikan, 6(3), 382-400.

Mustofa, M., Chodzirin, M., Sayekti, L., \& Fauzan, R. (2019). Formulasi Model Perkuliahan Daring Sebagai Upaya Menekan Disparitas Kualitas Perguruan Tinggi. Walisongo Journal of Information Technology, 1(2), 151-160. https://doi.org/10.21580/wjit.2019.1.2.4067.

Nash, M., \& Churchill, B. (2020). Caring during COVID-19: A gendered analysis of Australian university responses to managing remote working and caring responsibilities. Gender, Work and Organization, 27(5), 833-846. https://doi.org/10.1111/gwao.12484.

Prawiradilaga, D. S., \& Chaeruman, U. A. (2018). Modul Hypercontent Teknologi Kinerja (Performance Technology). Kencana.

Satrianingrum, A. P., \& Prasetyo, I. (2020). Persepsi Guru Dampak Pandemi Covid-19 terhadap Pelaksanaan Pembelajaran Daring di PAUD. Jurnal Obsesi : Jurnal Pendidikan Anak Usia Dini, 5(1), 633. https://doi.org/10.31004/obsesi.v5i1.574.

Siripongdee, K., Pimdee, P., \& Tuntiwongwanich, S. (2020). A blended learning model with IoT-based technology: effectively used when the COVID-19 pandemic? Journal for the Education of Gifted Young Scientists, 8(2), 905-917. https://doi.org/10.17478/jegys.698869.

Sugiyono. (2015). Metode Penelitian Pendidikan pendekatan Kuantitatif, Kualitatif dan R\&D. Alfabeta, Bandung.

Tegeh, I. M., Jampel, I. N., \& Pudjawan, K. (2015). Pengembangan buku ajar model penelitian pengembangan dengan model ADDIE. Seminar Nasional Riset Inovatif.

Yuzulia, I. (2021). The Challenges Of Online Learning During Pandemic: Students ' V oice. Jurnal Bahasa Dan Sastra, 13(1), 8-12. https://doi.org/10.31294/w.v13i1.9759. 